\title{
CIENCIA Y POLÍTICA
}

$\mathrm{R}$ ecurrentemente, en los países con menos desarrollo, se valora escasamente a la ciencia y la tecnología. Con ello se contaminan las propuestas que surgen del creciente número de personas que cree saber lo que se necesita sin comprender, en verdad, la complejidad que implican las políticas públicas para la ciencia y la tecnología.

Desde las décadas cargadas de ideologismos que nutrían, de seguro, diseños políticos, pasando por la era en que los economistas impregnaron a la sociedad, sin perjuicio que debe reconocerse su contribución a esta, a nuestro presente que mantiene algunas rigideces claramente incovenientes para un desarrollo sustentable en medio de un discurso culturalista, pero más bien mediático, la ciencia, no se ha abordado en lo político, salvo escasas excepciones, con el profesionalismo que nuestra época impone. Manfred Max-Neef expresó hace años que se puede escribir mucho sobre el amor, pero para saber de él se debe haber estado enamorado. Lo mismo ocurre en lo que concierne a la ciencia y la tecnología, las artes y las humanidades. Para saber bien de ellas, hay que haberlas vivido. Estas se viven, cuando las personas se empapan con lo que crean. Así se aprenden los vericuetos infinitos que el proceso de hacer ciencia de verdad, implican. Por de pronto, el imperativo de ponerla a prueba con pares exigentes para lo que existe una tradición centenaria.

Si bien administrar la ciencia es también tecnociencia, es insuficiente para sustentar el dise- ño de políticas públicas para fortalecer la ciencia y el desarrollo competitivo del país. La política requiere, en consecuencia, el aporte permanente de científicos y tecnólogos. Contribución que emana de su mérito como individuos y a través de las sociedades que los representan, si ella exige rigor a su membresía.

Quienes aspiran dirigir el país en los próximos años, no pueden eludir la responsabilidad de convocar al pensamiento de científicos y organizaciones académicas de excelencia para abordar el enorme déficit que tiene Chile en su desarrollo científico. Aunque en tiempos de elecciones parece que estas materias no interesan y que no existe precariedad en la dimensión del capital humano que tiene Chile, olvidando que buena parte de los que saben leer no entienden lo que leen, debemos insistir y reclamar la atención de la sociedad toda que habla de educación y margina de hecho la relevancia que tiene el pensamiento científico en esta.

Es de esperar que quienes sean nuestros candidatos a la presidencia puedan hacer público su pensamiento sobre esta materia y comprometerse con un camino que, en definitiva, nos permita arrancar del proceso más bien larvado que caracteriza el desarrollo de nuestra capacidad científica.

\section{MANUEL KRAUSKOPF}

Editor

Universidad Andrés Bello

Santiago, Chile

mkrausk@unab.cl 